\title{
Assessment Of Different Soil Amendment Effects On Tuberose Bulb Quality And Quantity
}

\author{
Zannatul Firdaus Binte Habib ${ }^{1}$, Dr. Md. Ismail Hossain ${ }^{2}$, \\ H. E. M. Khairul Mazed ${ }^{3 *}$, Tania Sultana ${ }^{4}$, Marjana Yeasmin ${ }^{5}$ \\ ${ }^{1}$ Lecturer, Dept. of AFES, Sher-e-Bangla Agricultural University, Bangladesh. \\ ${ }^{2}$ Professor, Dept. of Horticulture, Sher-e-Bangla Agricultural University, Bangladesh. \\ ${ }^{3}$ Ph.D. Student, Dept. of Horticulture, Sher-e-Bangla Agricultural University, Bangladesh. \\ ${ }^{4}$ Asst. Professor, Department of AFES, Sher-e-Bangla Agricultural University, Bangladesh. \\ ${ }^{5}$ Assistant Professor, Dept. of Agronomy, Sher-e-Bangla Agricultural University,Bangladesh. \\ *Corresponding Author
}

\begin{abstract}
A one year field experiment was conducted to elucidate the effectiveness of different soil organic amendments and chemical fertilizers on tuberose at the Floriculture Research Field, Bangladesh Agricultural Research Institute, Gazipur from March, 2014 to May 2015. The experiment consisted of nine treatments namely: $T_{l}=$ Farmyard manure $(5 \mathrm{t} / \mathrm{ha})+1 / 2$ (Recommended doses of fertilizer $(R D F)$ that is $N=150 \mathrm{~kg}, P=30$ $\mathrm{kg}, K=100 \mathrm{~kg}, S=20 \mathrm{~kg}, B=1 \mathrm{~kg}, \mathrm{Zn}=1 \mathrm{~kg}$ per hectare $) T_{2}=$ Farmyard manure $(10 \mathrm{t} / \mathrm{ha})+1 / 2 R D F, T_{3}=$ Poultry refuse $(5 \mathrm{t} / \mathrm{ha})+1 / 2 R D F, T_{4}=$ Poultry refuse $(10 \mathrm{t} / \mathrm{ha})+1 / 2 R D F, T_{5}=$ Vermicompost $(5 \mathrm{t} / \mathrm{ha})+1 / 2 R D F, T_{6}=$ Vermicompost $(10 \mathrm{t} / \mathrm{ha})+1 / 2 R D F, T_{7}=$ Bokashi $(3 \mathrm{t} / \mathrm{ha})+1 / 2 R D F, T_{8}=$ Bokashi $(5 \mathrm{t} / \mathrm{ha})+1 / 2 R D F$ and $T_{9}=$ Control (Recommended doses of fertilizer (RDF). The experiment was conducted in Randomized Block Design $(R C B D)$ with three replications. The results showed that application of organic amendments and fertilizer had significant variations on most of the parameters. The maximum vase life of flower, number of bulb/hill, number of bulblet/hill, bulb diameter, bulb weight, 10 bulblet weight, yield of bulb and yield of bulblet were obtained with the use of $10 \mathrm{t}$ tha vermicompost along with 50 percent recommended dose of fertilizer (RDF). In conclusion, application of $10 \mathrm{t} / \mathrm{h}$ a vermicompost along with fertilizers at a rat of $N=75 \mathrm{~kg}, P=15 \mathrm{~kg}, K=50 \mathrm{~kg}$, $S=10 \mathrm{~kg}, B=0.5 \mathrm{~kg}, \mathrm{Zn}=0.5 \mathrm{~kg}$ per hectare is recommended for durable flower and bulb production of tuberose.

Keywords: Tuberose, Vase life, Nutrient management, farmyard manure, vermicompost,Bokashi, Poulty refuse, Bulb production.
\end{abstract}

\section{Introduction}

Tuberose (PolianthestuberosaL.), which occupies place in ornamental horticulture belongs to Amaryllidaceae family was originated in Mexico and grown on large scale in Asia. Tuberose is a half hardy, bulbous perennial multiplying itself through bulb-bulblets, roots are mainly adventitious and shallow, the leaves are long narrow, linear, grass like, green and arise in rosette.In Bangladesh, its commercial cultivation was introduced during 1980 by some pioneer and innovative farmers at Panishara union of Jhikorgachathana under Jessore district near the Benapol border (Hoqueet al., 1992). Tuberose is a gross feeder and requires a large quantity of NPK, both in the form of organic and inorganic fertilizers (Amarjeet and Godara, 1998). Fertilizers have great influence on growth, building and flower production in tuberose. Effect of manures and chemical fertilizers on tuberose production has been reported by several authors for different geographical region (Yadavet al., 1985 and Singh et al., 2005). Nitrogen, phosphorus and potassium have a significant effect on floret quality and bulb production. Duration of flower in the field was improved through using organic fertilizer (Islam, 2011). Poultry manure is an excellent organic fertilizer, as it contains high nitrogen, phosphorus, potassium and other essential nutrients (Garg and Bahla, 2008). Vermicompost has been shown to have high levels of total and available nitrogen, phosphorus, potassium, micronutrients, microbial and enzyme activities and growth regulators (Chauhanet al., 2005). Mustard oil cake is an excellent source of organic amendment can replace not only the use of chemical fertilizers but also replace the use of pesticides by suppressing pathogens and insects (Bose et al., 1999). Research works have shown that compost and other organic manures like bokashi, farmyard manure, cocodust, water hyacinth, mustard oil cake, vermicompost etc. can serve as soil amendments to improve soil nutrient status, water holding capacity as well as increase vase life (Roe, 1997; Kabiret al., 2011). They also stabilize soil $\mathrm{pH}$, increase soil organic matter and ultimately improve plant growth, bulb yield and flower quality. 


\section{Site Description}

\section{Materials and Methods}

The experiment was conducted at the Floriculture Research Field, Horticulture Research Centre of Bangladesh Agricultural Research Institute (BARI), Gazipur. The location of the site was about $35 \mathrm{~km}$ North of Dhaka city with $24.09^{\circ} \mathrm{N}$ latitude and $90.26^{\circ} \mathrm{E}$ longitude and elevation of $8.40 \mathrm{~m}$ from the sea level. The experiment was laid out in a Randomized Complete Block Design (RCBD) with three replications. The unit plot size was $1.8 \mathrm{~m} \times 1.5 \mathrm{~m}$ accommodating 45 plants per plot. Two adjacent unit plots were separated by $60 \mathrm{~cm}$ space and there was $80 \mathrm{~cm}$ space between the blocks.

\section{Planting Materials}

Medium size (2.0-2.5 $\mathrm{cm}$ diameter) bulb of tuberose single cultivar (PT-001) was selected as experimental materials. The single ever blooming Mexican Tuberose is one of the most fragrant of cultivated plants.

\section{Experimental Treatments}

The experiment consisted of 9 treatments comprising of different level of organic amendments and fertilizer. $T_{1}=$ Farmyard manure $(5 \mathrm{t} / \mathrm{ha})+1 / 2 \mathrm{RDF}, \mathrm{T}_{2}=$ Farmyard manure $(10 \mathrm{t} / \mathrm{ha})+1 / 2 \mathrm{RDF}, \mathrm{T}_{3}=$ Poultry refuse $(5 \mathrm{t} / \mathrm{ha})+1 / 2 \mathrm{RDF}, \mathrm{T}_{4}=$ Poultry refuse $(10 \mathrm{t} / \mathrm{ha})+1 / 2 \mathrm{RDF}, \mathrm{T}_{5}=$ Vermicompost $(5 \mathrm{t} / \mathrm{ha})+1 / 2 \mathrm{RDF}, \mathrm{T}_{6}=$ Vermicompost $(10 \mathrm{t} / \mathrm{ha})+{ }^{1} / 2 \mathrm{RDF}, \mathrm{T}_{7}=$ Bokashi $(3 \mathrm{t} / \mathrm{ha})+1 / 2 \mathrm{RDF}, \mathrm{T}_{8}=$ Bokashi $(5 \mathrm{t} / \mathrm{ha})+1 / 2 \mathrm{RDF}$ and $\mathrm{T}_{9}=$ Control (Recommended doses of fertilizer (RDF) that is $\mathrm{N}=150 \mathrm{~kg}, \mathrm{P}=30 \mathrm{~kg}, \mathrm{~K}=100 \mathrm{~kg}, \mathrm{~S}=20 \mathrm{~kg}, \mathrm{~B}=1 \mathrm{~kg}, \mathrm{Zn}=1$ kg per hectare) (Halderet al., 2007).

\section{Preparation of Manures and Fertilizers}

Farm yard Manure is prepared basically using cow dung, cow urine, waste straw and other dairy wastes. Poultry refuseis basically a waste material which is organic in nature and comprises of urine and feces of animals which are related to poultry e.g. chicken. Poultry manure is a mixture of certain types of bedding material such as sawdust or wood shavings. This vermicompost was collected from Soil Science Division of BARI. Bokashi was made comprising fish meal, oil cake, bone meal, rice bran, poultry refuse at a rate of $20 \mathrm{~kg}$, $40 \mathrm{~kg}, 20 \mathrm{~kg}, 100 \mathrm{~kg}$ and $100 \mathrm{~kg}$, respectively. Bkashi were collected from Vegetable Division of HRC, BARI which is high in NPK and other micronutrients. Well-decomposed cow dung, poultry manure, vermicompost, bokashi, P, K, B, S and Zn were applied during final land preparation as per treatment. $\mathrm{N}$ was applied in three installments at 35,55 and 75 days after planting of bulbs.

\section{Data collection and Analysis}

Five plants were selected randomly for data collection of different parameters of the plant and flower. The recorded data on different parameters were statistically analyzed using 'MSTAT-C' software to find out the significance of variation resulting from the experimental treatments. The mean for the treatments was calculated and analysis of variance for each of the characters was performed by $\mathrm{F}$ (variance ratio) test. The differences between the treatment means were evaluated by Duncan's Multiple Range Test (DMRT) according to Steel $e t$ al., (1997) at $5 \%$ level of probability.

\section{Flower durability}

\section{Results And Discussion}

Maximum duration of flowering was observed in $T_{6}\left(15\right.$ days) followed by $T_{4}$ (13 days) (Figure 1). Application of vermicompost, poultry manure with fertilizer influenced flower longevity due to increased nutrient uptake by plant and greater development of water conducting tissues. It might also be due to the presence of ethylene inhibitors or due to presence of cytokinins which delay senescence of florets. The findings were in conformity with the finding of Kusuma (2000) in tuberose. The minimum flowering duration was in $\mathrm{T}_{9}$ ( 9 days). 


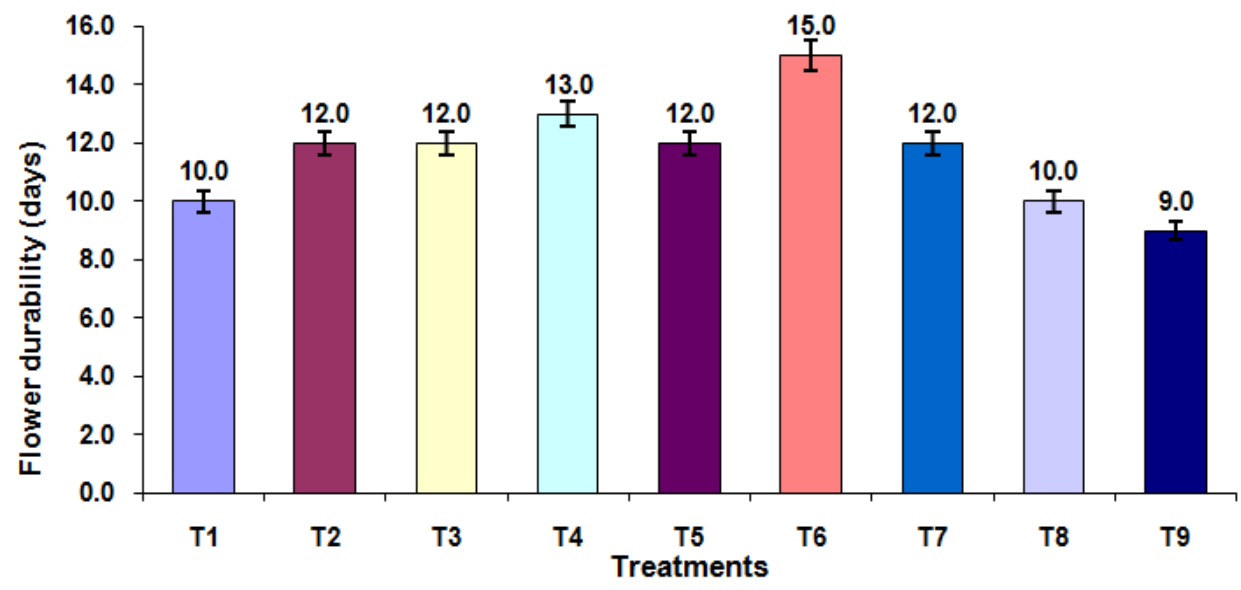

Fig 1.Effect of organic amendments and fertilizer on flower durability of tuberose

\section{Number of bulb/hill}

Number of bulb per hill showed significantly difference among the treatments (Table 1). The maximum number of bulb/hill (5.0) was found in $\mathrm{T}_{6}$ which was significantly higher than all other treatments. The lowest number of bulb per hill (2.5) was observed in $\mathrm{T}_{9}$ (control). Nutrient sources have great influence bulb production in tuberose (Mitraet al., 1979).

\section{Number of bulblet/hill}

Number of bulblet/hill showed a statistically significant variation for different treatments under present study. The maximum number of bulblet/hill (15.0) was recorded in $T_{6}$. The treatment $T_{9}$ produced minimum number of bulblets (6.0) (Table 1). Application of vermicompost (10 t/ha) $+1 / 2$ (Recommended Doses of Fertilizer) increased the number of bulb by 150 percent, compared to the untreated soil.

\section{Bulb diameter}

Data on the effect of different level of organic amendments and fertilizer on tuberose bulb diameter are presented in Table 1 . The largest bulb $(4.0 \mathrm{~cm})$ was produced in $\mathrm{T}_{6}$ which were statistically different from other treatments. The smallest bulb $(1.5 \mathrm{~cm})$ obtained from control. Application of vermicompost $(10 \mathrm{t} / \mathrm{ha})+1 / 2$ (Recommended Doses of Fertilizer) increased the bulb diameter by 166.66 percent, compared to the untreated soil. According to Padaganuret al., (2005) and Kabiret al., (2011), the bulb diameter was enhanced when vermicompost with fertilizer and poultry manure with fertilizer was applied in tuberose field.

\section{Bulb weight}

Weight of individual bulb showed statistically significant variation for different treatments under the present investigation (Table 1). The maximum weight $(40.0 \mathrm{~g})$ of individual bulb was recorded in $\mathrm{T}_{6}$ which was statistically different from other treatments and the minimum weight $(24.0 \mathrm{~g})$ of individual bulb was recorded in $\mathrm{T}_{9}$ (Control). Application of vermicompost (10 t/ha) +1/2 (Recommended Doses of Fertilizer) increased the bulb weight by 66.66 percent, compared to the untreated soil. In an experiment, treatment with vermicompost and poultry manure and fertilizer proved very effective for the development of bulbs (Padaganuret al., 2005) in tuberose.

Table 1.Effect of organic amendments and fertilizer on bulb production of tuberose

\begin{tabular}{|l|l|l|l|l|l|l|l|}
\hline Treatments & $\begin{array}{l}\text { Bulb } \\
\text { no. }\end{array}$ & $\begin{array}{l}\text { Bulblet } \\
\text { no. }\end{array}$ & $\begin{array}{l}\text { Bulb } \\
\text { diameter }\end{array}$ & $\begin{array}{l}\text { Bulb } \\
\text { weight }\end{array}$ & $\begin{array}{l}\text { 10 bulblet } \\
\text { wt. }\end{array}$ & $\begin{array}{l}\text { Yield of } \\
\text { bulb (t/ha) }\end{array}$ & $\begin{array}{l}\text { Yield } \\
\text { bulblet (t/ha) }\end{array}$ \\
\hline $\mathrm{T}_{1}$ & $3.0 \mathrm{ab}$ & $6.8 \mathrm{bc}$ & $1.6 \mathrm{~b}$ & $26.0 \mathrm{~cd}$ & $43.0 \mathrm{~cd}$ & $6.0 \mathrm{a}$ & $8.0 \mathrm{ab}$ \\
\hline $\mathrm{T}_{2}$ & $3.5 \mathrm{ab}$ & $8.9 \mathrm{bc}$ & $2.8 \mathrm{ab}$ & $32.0 \mathrm{bc}$ & $47.0 \mathrm{bc}$ & $7.5 \mathrm{a}$ & $8.5 \mathrm{ab}$ \\
\hline $\mathrm{T}_{3}$ & $3.8 \mathrm{ab}$ & $8.0 \mathrm{bc}$ & $2.7 \mathrm{ab}$ & $35.0 \mathrm{~b}$ & $48.0 \mathrm{bc}$ & $8.0 \mathrm{ab}$ & $9.0 \mathrm{ab}$ \\
\hline $\mathrm{T}_{4}$ & $4.0 \mathrm{ab}$ & $10.0 \mathrm{~b}$ & $2.8 \mathrm{ab}$ & $37.0 \mathrm{ab}$ & $51.5 \mathrm{ab}$ & $9.0 \mathrm{ab}$ & $10.5 \mathrm{ab}$ \\
\hline $\mathrm{T}_{5}$ & $3.8 \mathrm{ab}$ & $9.0 \mathrm{bc}$ & $2.6 \mathrm{ab}$ & $36.0 \mathrm{ab}$ & $50.0 \mathrm{~b}$ & $8.5 \mathrm{ab}$ & $10.0 \mathrm{ab}$ \\
\hline $\mathrm{T}_{6}$ & $5.0 \mathrm{a}$ & $15.0 \mathrm{a}$ & $4.0 \mathrm{a}$ & $40.0 \mathrm{a}$ & $55.0 \mathrm{a}$ & $10.0 \mathrm{a}$ & $12.0 \mathrm{a}$ \\
\hline $\mathrm{T}_{7}$ & $3.5 \mathrm{ab}$ & $9.5 \mathrm{bc}$ & $2.5 \mathrm{ab}$ & $34.0 \mathrm{bc}$ & $47.0 \mathrm{bc}$ & $8.0 \mathrm{ab}$ & $9.5 \mathrm{ab}$ \\
\hline $\mathrm{T}_{8}$ & $3.2 \mathrm{ab}$ & $7.0 \mathrm{bc}$ & $2.3 \mathrm{ab}$ & $30.0 \mathrm{c}$ & $45.2 \mathrm{c}$ & $7.0 \mathrm{ab}$ & $8.0 \mathrm{ab}$ \\
\hline $\mathrm{T}_{9}$ & $2.5 \mathrm{~b}$ & $6.0 \mathrm{c}$ & $1.5 \mathrm{~b}$ & $24.0 \mathrm{~d}$ & $40.0 \mathrm{~d}$ & $5.0 \mathrm{~b}$ & $7.5 \mathrm{~b}$ \\
\hline $\mathbf{C V}$ & $\mathbf{7 . 7}$ & $\mathbf{8 . 9}$ & $\mathbf{8 . 5}$ & $\mathbf{9 . 2}$ & $\mathbf{1 0 . 3}$ & $\mathbf{1 0 . 5}$ & $\mathbf{9 . 8}$ \\
\hline
\end{tabular}




\section{0 bulblet weight $(\mathrm{g})$}

A statistically significant variation was recorded for different treatments in terms of 10 bulblet weight (Table 1). The highest weight $(55.0 \mathrm{~g})$ was recorded in $\mathrm{T}_{6}$ treatment. On the other hand, the lowest $(40.0 \mathrm{~g})$ weight of ten bulblet was recorded in control condition. Application of vermicompost $(10$ t/ha $)+1 / 2$ (Recommended Doses of Fertilizer) increased the ten bulblet weight by 37.50 percent, compared to the untreated soil. Mazedet al., (2015) and Kabir et al., (2011) which supports the present findings in tuberose.

\section{Yield of bulb per hectare}

Yield of bulb per hectare showed statistically significant difference for the application of organic amendments with fertilizer (Table 1). The highest yield of bulb per hectare (10.0 ton) was recorded from $\mathrm{T}_{6}$ and the lowest yield of bulb per hectare (5.0 ton) was attained from $\mathrm{T}_{9}$ (Table 1). Application of vermicompost (10 t/ha) $+1 / 2$ (Recommended Doses of Fertilizer) increased the number of bulb per hectare by 100 percent, compared to the untreated soil. These results are consistent with the result of Mazedet al., (2015) who reported that application of organic amendments with chemical fertilizers increased bulb yield.

\section{Yield of bulblet per hectare}

Application of organic amendments with fertilizer varied significantly on yield of bulblet per hectare (Table 1). The highest yield of bulblet per hectare (12.0 ton) was obtained from $\mathrm{T}_{6}$ while, the lowest yield of bulblet per hectare (7.5 ton) was recorded from $T_{9}$ (Table 1). Application of vermicompost $(10 \mathrm{t} / \mathrm{ha})+1 / 2$ (Recommended Doses of Fertilizer) increased the number of bulblet per hectare by 60 percent, compared to the untreated soil. These results were in line as reported by Kabiret al., (2011) in tuberose.

\section{Conclusion}

It may be concluded that application of vermicompost $10 \mathrm{t} / \mathrm{ha}$ along with 50 percent recommended dose of fertilizer (RDF) that is $\mathrm{N}=150 \mathrm{~kg}, \mathrm{P}=30 \mathrm{~kg}, \mathrm{~K}=100 \mathrm{~kg}, \mathrm{~S}=20 \mathrm{~kg}, \mathrm{~B}=1 \mathrm{~kg}, \mathrm{Zn}=1 \mathrm{~kg}$ per hectare showed significant improvement in vase life of flower, yield of bulb and bulblets through increased of various nutrients in the soil. Therefore, it is beneficial for tuberose cultivation and may be recommended for flower and bulb production commercially.

\section{References}

[1]. Amarjeet S and Godara NR(1998).Effect of nutritional requirement of tuberose (PolianthestuberosaL.) cv. Single on flower yield characters.Haryana Agric. Univ. J. Res. 28 (1):15- 20.

[2]. Bose TK, Maiti RG, Dhua RS and Das P(1999). Tuberose.In: Floriculture and Landscaping. Nayaprakash, Calcutta, India. pp. 505 514

[3]. Chauhan S, Singh CN and Singh AK(2005).Effect of vermicompost and pinching on growth and flowering in marigold.cv. PusaNarangiGainda. Prog. Hort.37(2): 419-422

[4]. Garg S and Bahla GS(2008).Phosphorus availability to maize as influenced by organic manures.BioRes. Technol. 99:773-777.

[5]. Halder NK, Siddiky MA, Ahmed RR, Sharifuzzaman SM and Ara KA(2007).Performance of tuberose as Influenced by Boron and Zinc.South Asian J. Agric.,2 (1\&2): 51-56.

[6]. Hoque AMM, Mannan MA, Rafiuddin MA, Hossain E and Akhtar MS(1992).Effect of size and number of bulbs per hill on the yield of tuberose (Polianthestuberosa L.).Bangladesh Hort. 20 (1): 81-83.

[7]. Islam F(2011). Influence of organic amendments and EM on yield and preservatives on vase life of gladiolus. An MS thesis submitted to Dept. of Horticulture. BSMRAU, Salna, Gazipur. 60 p.

[8]. Kabir K, Sharifuzzaman SM, Ara KA, Rahman BMS and Rahman MH(2011). Vase life and quality of tuberose cut flowers as influenced by different preservative solutions. Int. J. BioRes.10 (5): 14-21.

[9]. Kabir AKM, Iman MH, Mondal MMA and Chowdhury S(2011).Response of tuberose to integrated nutrient management. J. Enviorn. Sic. \& Natural Resources.4 (2): 55-59.

[10]. Kusuma G(2000).Effect of organic and inorganic fertilizers on growth, yield and quality of golden rod.An M.Sc. (Hort.) Thesis Univ. Agric. Sci. Bangalore, India. $60 \mathrm{p}$.

[11]. Mazed HEMK, Pulok AI, Rahman H, Monalesa N and Partho, SG(2015).Growth and yield of tuberose as influenced by different levels of manures and fertilizers.International J. Multidisciplinary Res. Dev.2 (4): 555-558.

[12]. Mitra SN, Munshi PS and Roy S(1979).Effect of different levels of nitrogen and bulb size on growth and flowering of tuberose (Polianthestuberosa L.).Indian Agric .23 (3): 185-188.

[13]. Padaganur VG, MokashiANandPatil VS(2005). Flowering, flower quality and yield of tuberose (Polianthestuberosa L.) as influenced by vermicompost, farmyard manure and fertilizers.Karnataka J. Agric. Sci.,18 (3):729-734

[14]. Roe NE, Stofella PJ and Graetz DA(1997). Compost from various municipal waste feed stocks affects crops growth, yield and fruit quality. J. American Soc. Hort. Sci. 122: 433-437.

[15]. Singh SRP, Dhiraj K, Singh VK and Dwivedi R(2005).Effect of NPK fertilizers on growth and flowering of tuberose cv. Single.Haryana J. Hort. Sci.34:84-86

[16]. Steel RGD, Torrie JH and Dickey DA(1997).Principles and Procedures of Statistics.A Biometric Approach.3 ${ }^{\text {rd }}$ ed. McGraw Hill Book Co. Inc., New York. pp. 107-109.

[17]. Yadav LP, Bose TK and Maity RG(1985).Response of tuberose (Polianthestuberosa L.) to nitrogen and phosphorus fertilization Prog. Hort.17 (2): 83-86. 